\title{
ANALISIS KECENDERUNGAN PENERIMAAN OPINI AUDIT GOING CONCERN PADA PERUSAHAAN MANUFAKTUR
}

\author{
Yunus Harjito \\ Fakultas Ekonomi dan Bisnis Universitas Muhammadiyah Surakarta \\ Email: yunus_accounting@yahoo.co.id
}

\begin{abstract}
This study aims to predict the effect of audit quality, financial condition, the growth of the company, the previous year's audit opinion, firm size, and debt-to-equity ratio of the tendency of going-concern audit opinion. In this study the type of data used is quantitative data with a population of 145 companies listed in Indonesia Stock Exchange in 2008-2012. The analytical method used is logistic regression analysis with sample totaling 20 companies were selected based on purposive sampling method for 5 periods. Based on the analysis it can be concluded that the quality of the audit significant negative effect on the going-concern audit opinion, the financial condition of the company has no significant effect on the going-concern audit opinion, the growth of the company has no significant effect on the going-concern audit opinion, the previous year's audit opinion has no effect significantly to the going-concern audit opinion, the size of the company does not have a significant effect on the going-concern audit opinion, and debt-to-equity ratio does not significantly influence the going-concern audit opinion.
\end{abstract}

Key words: going concern audit opinion, audits quality, financial condition, the growth of the company, previous year's audit opinion, company size, debt-to-equity ratio.

\begin{abstract}
Abstrak: Penelitian ini bertujuan untuk memprediksi pengaruh kualitas audit, kondisi keuangan perusahaan, pertumbuhan perusahaan, opini audit tahun sebelumnya, ukuran perusahaan, dan rasio debt-to-equity terhadap kecenderungan opini auditgoing concern. Dalam penelitian ini jenis data yang digunakan adalah data kuantitatif dengan populasi 145 perusahaan yang terdaftar di Bursa Efek Indonesia pada tahun 20082012. Metode analisis yang digunakan adalah analisis regresi logistik dengan sampel sebanyak 20 perusahaan yang dipilih berdasarkan metode purposive sampling selama 5 periode. Berdasarkan hasil analisis dapat disimpulkan bahwa kualitas audit berpengaruh negatif signifikan terhadap opini audit going concern, kondisi keuangan perusahaan tidak berpengaruh signifikan terhadap opini audit going concern, pertumbuhan perusahaan tidak berpengaruh signifikan terhadap opini audit going concern, opini audit tahun sebelumnya tidak berpengaruh signifikan terhadap opini audit going concern, ukuran perusahaan tidak memiliki pengaruh yang signifikan terhadap opini audit going concern, dan rasio debt-toequitytidak berpengaruh signifikan terhadap opini audit going concern.
\end{abstract}

Kata kunci: opini audit going concern, kualitasaudit, kondisi keuangan, pertumbuhan perusahaan, opini audit tahun sebelumnya, ukuran perusahaan, rasio debt-to-equity.

\section{PENDAHULUAN}

Keberhasilan perusahaan dalam mempertahankan kepercayaan para investor dapat dibuktikan dengan banyaknya para investor yang telah menginvestasikan dananya pada 
perusahaan tersebut. Hal ini menjadi tantangan perusahaan untuk terus memperoleh kepercayaan investor agar menginvestasikan dananya kepada perusahaan dan investor yang lama tetap setia terhadap perusahaan. Salah satu hal yang dilirik oleh investor untuk mau menginvestasikan dananya adalah pengeluaran opini going concern yang diperoleh oleh perusahaan. Pengeluaran opini going concern sangat berguna bagi para investor untuk membuat keputusan yang tepat dalam berinvestasi. Perlunya untuk mengetahui sehat tidaknya kondisi keuangan perusahaan yang merupakan asumsi dasar bagi investor dalam menentukan investasinya, terutama menyangkut kelangsungan hidup perusahaan tersebut.

Peluang perusahaan untuk memperoleh opini going concern sangat ditentukan oleh kondisi sesungguhnya yang ada pada perusahaan dan pihak manajemen untuk mengelola perusahaan dengan baik. Widyantari (2011) menjelaskan bahwa pihak manajemen yang mempunyai kepentingan tertentu akan cenderung menyusun laporan keuangan yang sesuai dengan tujuannya dan bukan demi kepentingan prinsipal. Perilaku manajemen ini tentu saja dapat memengaruhi kualitas dari laporan keuangan yang disajikan. Oleh karena itu, diperlukan peran auditor independen untuk memberikan opininya atas kewajaran laporan keuangan perusahaan yang terdiri dari laporan posisi keuangan, laporan laba rugi komprehensif, laporan laba ditahan, dan laporan arus kas. Dengan demikian, diharapkan penyedia modal dan pemegang kepentingan lainnya dapat membuat keputusan investasi, kredit, dan keputusan alokasi sumber daya lainnya yang lebih tepat berdasarkan informasi yang telah diaudit oleh pihak independen.

Selain itu, peran auditor dalam mengaudit laporan keuangan perusahaan sangat dituntut untuk dapat melakukan pemeriksaanya secara profesional.Hal ini membuat auditor mempunyai tanggung jawab yang besar untuk mengeluarkan opini going concern yang konsisten dengan keadaan sesungguhnya dari perusahaan tersebut. SPAP seksi 341 menyebutkan bahwa auditor juga bertanggung jawab untuk menilai apakah terdapat kesangsian besar terhadap kemampuan satuan usaha dalam mempertahankan kelangsungan hidupnya (going concern) dalam periode waktu yang pantas, tidak lebih dari satu tahun sejak tanggal laporan audit.

Going concern adalah kelangsungan hidup suatu entitas. Dengan adanya going concern maka suatu entitas dianggap akan mampu mempertahankan kegiatan usahanya dalam jangka panjang, tidak akan dilikuidasi dalam jangka waktu pendek. Laporan audit dengan modifikasi mengenai going concern merupakan suatu indikasi bahwa dalam penilaian auditor terdapat risiko auditee tidak dapat bertahan dalam bisnis. Dari sudut pandang auditor, keputusan tersebut melibatkan beberapa tahap analisis. Auditor harus mempertimbangkan hasil dari operasi, kondisi ekonomi yang mempengaruhi perusahaan, kemampuan membayar hutang, dan kebutuhan likuiditas di masa yang akan datang (Setyarno et.al., 2006). Keberadaan entitas bisnis merupakan ciri dari sebuah lingkungan ekonomi, yang dalam jangka panjang bertujuan untuk mempertahankan kelangsungan hidup (going concern) usahanya melalui asumsi going concern. Kelangsungan hidup usaha selalu dihubungkan dengan kemampuan manajemen dalam mengelola perusahaan agar bertahan hidup (Praptitorini dan Januari 2007). Faktor yang mendorong auditor mengeluarkan opini going concern penting untuk diketahui karena opini ini dapat dijadikan referensi investor berkaitan investasinya. Auditor dipandang sebagai pihak independen yang mampu memberikan pernyataan yang bermanfaat mengenai kondisi keuangan klien (Fany dan Saputra, 2005). 
Widyantari (2011) menjelaskan bahwa opini going concern yang diterima oleh sebuah perusahaan menunjukkan adanya kondisi dan peristiwa yang menimbulkan keraguan auditor akan kelangsungan hidup perusahaan. Salah satu pertimbangan yang perlu diperhatikan oleh auditor dalam memberikan opini going concern adalah meramalkan apakah auditee akan mengalami kebangkrutan atau tidak.Opini audit dengan modifikasi mengenai going concern, mengindikasikan bahwa dalam penilaian auditor terdapat resiko perusahaan tidak dapat bertahan dalam bisnis yang normal. Di lain pihak, perusahaan yang mempunyai kondisi keuangan yang baik atau sehat memperoleh opini "standart" atau "unqualified". Dari sudut pandangan auditor, keputusan tersebut melibatkan beberapa tahap analisis. Auditor harus mempertimbangkan hasil dari operasi, kondisi ekonomi yang mempengaruhi perusahaan, kemampuan membayar hutang, dan kebutuhan likuiditas di masa yang akan datang (Lenard et.al., 1998 dalam Ramadhany, 2004). Pentingnya informasi tentang opini going concern mendorong peneliti untuk menganalisis faktor-faktor yang memepengaruhi pemberian opini audit going concern ini.

Penelitian ini diharapkan dapat menambah wawasan dan ilmu pengetahuan serta referensi penelitian berikutnya berkaitan dengan faktor-faktor yang mempengaruhi penerimaan opini audit going concern pada perusahaan manufaktur. Selain itu, penelitian ini juga diharapkan sebagai masukan kepada perusahaan-perusahaan manufaktur dalam upaya meningkatkan dan perbaikan kinerja.Bagi kantor akuntan publik terutama bagi auditor, penelitian ini diharapkan dapat memberikan masukan dalam memberikan penilaian mengenai keputusan opini audit yang mengacu pada kelangsungan hidup perusahaan di masa yang akan datang.Bagi investor, ketika akan berinvestasi dapat melihat bagaimana kelangsungan hidup perusahaan baik atau tidak serta mempunyai bahan pertimbangan dalam menentukan keputusan investasi.

\section{KAJIAN TEORI}

Teori Agensi (Agency Theory). Jensen and Meckling (1976)mendefinisikan bahwa hubungan keagenan sebagai suatu kontrak, dimana satu orang atau lebih (prinsipal) meminta pihak lainnya (agen) untuk melaksanakan sejumlah pekerjaan atas nama prinsipal, yang melibatkan pendelegasian beberapa wewenang pembuatan keputusan kepada agen. Jika kedua pihak yang terlibat dalam kontrak tersebut berusaha untuk memaksimalkan utilitas mereka, maka ada kemungkinan bahwa agen tidak akan selalu bertindak untuk kepentingan terbaik prinsipal. Dengan tujuan memotivasi agen, maka prinsipal merancang kontrak sedemikan rupa sehingga mampu mengakomodasi kepentingan pihak-pihak yang terlibat dalam kontrak keagenan.

Eisenhardt (1989) menyatakan ada tiga asumsi sifat manusia terkait teori keagenan yaitu (1) Manusia pada umumnya mementingkan diri sendiri (self-interest), (2) Manusia memiliki daya pikir terbatas mengenai persepsi masa mendatang (bounded rationality) dan (3) Manusia selalu menghindari risiko (risk-averse). Berdasarkan asumsi sifat dasar manusia tersebut manajer akan cenderung bertindak oportunis, yaitu mengutamakan kepentingan pribadi. Hal ini memicu terjadinya konflik keagenan sehingga diperlukan peran pihak ketiga yaitu auditor independen untuk mengevaluasi pertanggungjawaban keuangan manajemen, dan memberikan pendapat mengenai kewajaran laporan keuangan yang disajikan oleh manajemen.

Saputra (2012) menyebutkan teori agensi mengasumsikan bahwa semua individu bertindak atas kepentingan mereka sendiri. Pemilik perusahaan sebagai principal 
diasumsikan hanya tertarik kepada hasil keuangan yang bertambah atau investasi mereka di dalam perusahaan, sedangkan para manager sebagai agent diasumsikan menerima kepuasan berupa kompensasi keuangan dan terpenuhinya syarat-syarat yang menyertai dalam hubungan tersebut. Oleh karena adanya perbedaan kepentingan tersebut, maka perlu adanya pihak ketiga, atau pihak independen yang memjembatani antara hubungan agent dan principal, sehingga silang kepentingan antara agent dan principal tidak mengganggu keberlangsungan hidup entitas. Pihak ketiga yang memoderasi antara manajemen dan pemilik adalah akuntan publik (auditor).

Auditing dan Opini Audit. Auditing merupakan suatu proses sistematik untuk memperoleh dan mengevaluasi bukti secara objektif mengenai pernyataan-pernyataan tentang kegiatan dan kejadian ekonomi dengan tujuan untuk menetapkan tingkat kesesuaian antara pernyataan-pernyataan tersebut dengan kriteria yang telah ditetapkan, serta penyampaian hasil-hasilnya kepada pemakai yang berkepentingan (Mulyadi, 2002). Tujuan audit atas laporan keuangan oleh auditor independen pada umumnya adalah untuk menyatakan pendapat tentang kewajaran dalam semua hal yang material, posisis keuangan, hasil usaha, perubahan ekuitas, dan arus kas sesuai dengan standar akuntansi keuangan Indonesia. Jenis auditing dibagi menjadi tiga, yaitu audit laporan keuangan, audit operasional, dan audit ketaatan (Arens dan Loebbecke, 1997).

Standar Auditing. Standar auditing atau norma pemeriksaan dapat diartikan sebagai sesuatu yang ditentukan oleh penguasa sebagai suatu peraturan atau pedoman untuk mengukur kualitas, nilai, kuantitas, berat,luas, dan dalam hubungannya dengan auditing, maka standar auditing merupakan suatu mutu professional (professional qualities) auditor independen dan pertimbangan (judgement) yang digunakan dalam pelaksanaan audit dan penyusunan laporan auditor (Munawir, 1997).

Laporan dan Opini Audit. Laporan audit merupakan media yang dipakai oleh auditor dalam berkomunikasi dengan masyarakat dan lingkungannya. Dalam laporan audit, auditor menyatakan pendapatnya mengenai kewajaran laporan keuangan auditan. Pendapat auditor tersebut disajikan dalam suatu laporan tertulis yang umunya berupa laporan audit bentuk baku. Dalam bentuk baku laporan audit terdiri dari tiga paragraf, yaitu paragraf pengantar, paragraf lingkup audit, dan paragraf opini (Mulyadi, 2002).

Dalam paragraf pertama atau paragraf pengantar terdapat tiga kalimat utama, yaitu kalimat pertama menjelaskan objek yang menjadi sasaran auditing, kalimat kedua, dan ketiga menjelaskan tanggung jawab manajemen dan auditor. Paragraf kedua lingkup audit berisi pernyataan auditor bahwa auditnya dilaksanakan berdasarkan standar auditing yang ditetapkan oleh organisasi profesi akuntan publik dan beberapa penjelasan tambahan tentang standar audititng tersebut,serta suatu pernyataan keyakinan bahwa audit yang dilaksanakan mampu memberikan dasar yang memadai bagi auditor untuk memberikan pendapat atas laporan keuangan auditan.Paragraf ketiga adalah paragraf opini, yaitu merupakan paragraf yang didunakan oleh auditor untuk menyatakan pendapatnya mengenai laporan keuangan dalam paragraf pengantar.

Opini audit merupakan pernyataan yang dikeluarkan oleh auditor setelah mengaudit laporan keuangan suatu entitas. Mulyadi (2002) menjelaskan bahwa terdapat lima jenis pendapat auditor, yaitu: (1) Pendapat wajar tanpa pengecualian (unqualified opinion), (2)Pendapat wajar tanpa pengecualian dengan bahasa penjelas (unqualified opinion with 
explanatory language), (3)Pendapat wajar dengan pengecualian (qualified opinion), (4)Pendapat tidak wajar (adverse opinion), dan (5) Tidak memberikan pendapat (disclaimer of opinion).

Going concern dalam Akuntansi dan Pengauditan. Junaidi dan Jogiyanto(2010) menyebutkan bahwa suatu asumsi yang mendasari proses akuntansi adalah bahwa perusahaan melaporkan akan melanjutkan sebagai suatu going concern. Artinya suatu entitas dianggap mampu mempertahankan usahanya dalam jangka panjang dan tidak akan dilikuidasi. Laporan keuangan mengukur mengenai informasi posisi keuangan suatu entitas dan hasil dari operasi. Laporan auditor menambah dimensi kualitatif terhadap suatu informasi. Auditor merupakan perantara antara penyedia laporan keuangan dan pengguna laporan tersebut.

Going concern dipakai sebagai asumsi dalam pelaporan keuangan sepanjang tidak terbukti adanya informasi yang menunjukkan hal berlawanan (contrary information). Biasanya informasi yang secara signifikan dianggap berlawanan dengan asumsi kelangsungan hidup satuan usaha adalah berhubungan dengan ketidakmampuan satuan usaha dalam memenuhi kewajiban pada saat jatuh tempo tanpa melakukan penjualan sebagian besar aktiva kepada pihak luar melalui bisnis biasa, restrukturisasi utang, perbaikan operasi yang dipaksakan dari luar dan kegiatan serupa yang lain (PSA No. 30).Setyarno et.al (2006) menyebutkan going concern adalah kelangsungan hidup suatu entitas. Dengan adanya going concern maka suatu entitas dianggap akan mampu mempertahankan kegiatan usahanya dalam jangka panjang, dan tidak akan dilikuidasi dalam jangka waktu pendek.

Kualitas Audit. Junaidi dan Jogiyanto (2010) menyatakan bahwa auditor bertanggung jawab untuk menyediakan informasi yang berkualitas tinggi dan yang bermanfaat bagi pengambilan keputusan. Auditor yang bereputasi baik cenderung akan menerbitkan opini audit going concern jika klien terdapat masalah berkaitan going concern perusahaan. Craswell, et al. (2008) menyatakan bahwa, klien biasanya mempersepsikan auditor yang berasal dari Kantor Akuntan Publik besar dan yang memiliki afiliasi dengan Kantor Akuntan Publik internasional, memiliki kualitas yang lebih tinggi karena auditor tersebut memiliki karakteristik yang dapat dikaitkan dengan kualitas, seperti pelatihan, pengakuan internasional, serta adanya peer review. Reputasi auditor sering digunakan sebagai proksi dari kualitas audit, namun demikian dalam banyak penelitian kompetensi dan independensi masih jarang digunakan untuk melihat seberapa besar kualitas audit secara aktual (Ruiz Barbadillo et. al., 2004).

Reputasi auditor didasarkan pada kepercayaan pemakai jasa auditor, bahwa auditor memiliki kekuatan monitoring yang secara umum tidak dapat diamati. DeAngelo (1981) menyatakan bahwa auditor skala besar memiliki insentif yang lebih untuk menghindari kritikan kerusakan reputasi dibandingkan pada auditor skala kecil. Auditor skala besar juga lebih cenderung untuk mengungkapkan masalah-masalah yang ada karena mereka lebih kuat menghadapi risiko proses pengadilan. Argumen tersebut berarti bahwa auditor skala besar memiliki insentif lebih untuk mendeteksi dan melaporkan masalah going concern kliennya.

Mutchler et. al., (1997) menemukan bukti univariat bahwa auditor big 6 lebih cenderung menerbitkan opini audit going concern pada perusahaan yang mengalami financial distress dibandingkan auditor non big 6 . Auditor skala besar dapat menyediakan 
kualitas audit yang lebih baik dibanding auditor skala kecil, termasuk dalam mengungkapkan masalah going concern. KAP yang tergolong dalam Big Four memiliki kriteria untuk dapat masuk kedalamnya berdasarkan nominal pendapatannya serta banyaknya jumlah karyawan. Semakin besar skala auditor, akan semakin semakin besar kemungkinan auditor untuk menerbitkan opini audit going concern.Dari uraian tersebut, maka dapat dirumuskan hipotesis sebagai berikut:

H1: Kualitas audit berpengaruh positif terhadap penerimaan opini audit going concern.

Kondisi Keuangan Perusahaan. Kondisi keuangan perusahaan menggambarkan tingkat kesehatan perusahaan sesungguhnya (Ramadhany, 2004). Selain itu, McKeown et al. (1991)menemukan bukti bahwa, auditor hampir tidak pernah memberikan opini audit going concern pada perusahaan yang tidak mengalami kesulitan keuangan. Krishnan (1996) juga menyatakan bahwa auditor lebih cenderung untuk mengeluarkan opini audit going concern ketika kemungkinan kebangkrutan berada diatas $28 \%$ dengan menggunakan model prediksi Zmijeski. Carcello \& Neal (2000) menyatakan bahwa, semakin buruk kondisi keuangan perusahaan maka semakin besar probabilitas perusahaan menerima opini going concern.Beberapa penelitian sebelumnya menyimpulkan bahwa model prediksi kebangkrutan menggunakan rasio-rasio keuangan lebih akurat dibandingkan pendapat auditor dalam mengelompokkan perusahaan bangkrut dan tidak bangkrut (Altman \& McGough 1974, Koh \&Killough 1990, dan Koh 1991).Dari uraian tersebut, maka dapat dirumuskan hipotesis sebagai berikut:

$\mathrm{H} 2$ : Kondisi keuangan perusahaan berpengaruh negatif terhadap kemungkinan penerimaan opini going concern.

Pertumbuhan Perusahaan. Pertumbuhan perusahaan diproksikan dengan rasio pertumbuhan penjualan. Rasio ini mengukur seberapa baik perusahaan mempertahankan posisi ekonominya, baik dalam industrinya maupun dalam kegiatan ekonomi secara keseluruhan (Weston dan Copeland, 1992). Penjualan merupakan kegiatan operasi utama auditee. Auditee yang mempunyai rasio pertumbuhan penjualan yang positif mengindikasikan bahwa auditee dapat mempertahankan posisi ekonominya dan lebih dapat mempertahankan kelangsungan hidupnya (going concern). Penjualan yang terus meningkat dari tahun ke tahun akan memberi peluang auditee untuk memperoleh peningkatan laba. Semakin tinggi rasio pertumbuhan penjualan auditee, akan semakin kecil kemungkinan auditor untuk menerbitkan opini audit going concern. Perusahaan yang mengalami pertumbuhan, menunjukkan aktivitas operasional perusahaan berjalan dengan semestinya sehingga perusahaan dapat mempertahankan posisi ekonomi dan kelangsungan hidupnya, sedangkan perusahaan dengan negative growth mengindikasikan kecenderungan yang lebih besar ke arah kebangkrutan (Altman, 1968). Dari uraian di atas maka hipotesis selanjutnya adalah sebagai berikut:

H3: Pertumbuhan perusahaan berpengaruh negatif terhadap kemungkinan penerimaan opini audit going concern.

Opini Audit Tahun Sebelumnya. Mutchler (1984) melakukan wawancara dengan praktisi auditor yang menyatakan bahwa perusahaan yang menerima opini audit going concern pada tahun sebelumnya lebih cenderung untuk menerima opini yang sama pada tahun berjalan. Mutchler (1985) menguji pengaruh ketersediaan informasi publik terhadap prediksi opini audit going concern, yaitu tipe opini audit yang telah diterima perusahaan. 
Hasilnya menunjukkan bahwa model discriminant analysis yang memasukkan tipe opini audit tahun sebelumnya mempunyai akurasi prediksi keseluruhan yang paling tinggi sebesar 89,9 persen dibanding model yang lain. Penelitian oleh Carcello dan Neal (2000) serta Rahmadhany (2004) memperkuat bukti mengenai opini audit going concern yang diterima tahun sebelumnya dengan opini audit going concern tahun berjalan. Ada hubungan positif yang signifikan antara opini audit going concern tahun sebelumnya dengan opini audit going concern tahun berjalan. Apabila pada tahun sebelumnya auditor telah menerbitkan opini audit going concern, maka akan semakin besar kemungkinan auditor untuk menerbitkan kembali opini audit going cocern pada tahun berikutnya.Auditee yang menerima opini audit going concern pada tahun sebelumnya akan dianggap memiliki masalah kelangsungan hidupnya, sehingga semakin besar kemungkinan bagi auditor untuk mengeluarkan opini audit going concern pada tahun berjalan. Perusahaan yang bermasalah akan mengalami permasalahan seperti, hilangnya kepercayaan publik sehingga akan semakin mempersulit manajemen perusahaan untuk mengatasi kesulitan yang ada (Ramadhany, 2004). Setyarno et al. (2007), Ramadhany (2004),Januarti dan Fitrianasari (2008), Fanny dan Saputra (2000), Praptotorini dan Indira Januarti (2007) menemukan bukti bahwa opini audit tahun sebelumnya signifikan mempengaruhi penerimaan opini audit going concern. Hal ini menunjukan bahwa dengan auditee menerima opini audit going concern pada tahun sebelumnya, maka besar kemungkinaan auditee tersebut akan menerima opini audit serupa pada tahun berjalan. Dari uraian tersebut maka dapat disusun hipotesis sebagai berikut:

H4: Opini audit tahun sebelumnya berpengaruh positif terhadap kemungkinan penerimaan opini audit going concern.

Ukuran Perusahaan. Ukuran perusahaan dapat dilihat dari kondisi keuangan perusahaan misalnya besarnya total aset. Sujiyanto (2001) dalam penelitiannya mengunakan penjualan atau asset untuk mengukur besarnya perusahaan, jika pertumbuhannya bernilai positif maka dapat mencerminkan besarnya ukuran perusahaan. Menurut Widyantari (2011) ukuran perusahaan dapat dilihat dari total aktiva yang dimiliki. Perusahaan dengan total aktiva yang besar menunjukkan bahwa perusahaan tersebut telah mencapai tahap kedewasaan karena dalam tahap ini arus kas perusahaan sudah positif dan dianggap memiliki prospek yang baik dalam jangka waktu yang relatif panjang. Mutchler (dalam Santosa dan Wedari, 2007), menyatakan bahwa auditor lebih sering mengeluarkan modifikasi opini audit going concern pada perusahaan yang lebih kecil, hal ini dimungkinkan karena auditor mempercayai bahwa perusahaan yang lebih besar dapat menyelesaikan kesulitan-kesulitan keuangan yang dihadapinya daripada perusahaan yang lebih kecil.Januarti dan Fitrianasari (2008), Junaidi dan Jogiyanto Hartono (2010) menemukan bahwa ukuran perusahaan tidak berpengaruh terhadap penerimaan opini audit going concern, sedangkan Santosa dan Wedari (2007) menemukan bukti bahwa ukuran perusahaan berpengaruh pada opini going concern. Hal ini menunjukkan semakin besar ukuran perusahaan akan semakin kecil kemungkinan menerima opini audit going concern. Maka dari uraian di atas dapat dirumuskan hipotesis sebagai berikut:

H5: Ukuran perusahaan berpengaruh negatif terhadap kemungkinan penerimaan opini audit going concern.

Utang (Debt to Equity Ratio). Chen dan Cruch (1992) menyatakan bahwa, perusahaan yang memiliki aset lebih kecil daripada kewajibannya akan menghadapi bahaya 
kebangkrutan. Debt to equity ratio diukur dengan membandingkan antara total kewajiban dengan total equity. Rasio ini mengukur tingkat persentase utang perusahaan terhadap total aset yang dimiliki, semakin besar tingkat debt to equity ratio menyebabkan timbulnya keraguan akan kemampuan perusahaan untuk mempertahankan kelangsungan usahanya, karena sebagian besar dana yang diperoleh oleh perusahaan akan digunakan untuk membiayai utang dan dana untuk beroperasi akan semakin berkurang. Kreditor pada umumnya lebih menyukai debt ratio yang rendah angka rasionya, karena akan semakin besar kemungkinan dari kerugian yang dialami kreditor jika terjadi likuidasi. Semakin besar debt ratio maka akan semakin besar kemungkinan auditor untuk memberikan opini audit going concern. Hasil penelitian Praptitorini dan Januarti (2007), Januarti dan Fitriasari (2008), serta Januarti (2009) menemukan bahwa rasio debt default berpengaruh positif signifikan terhadap penerimaan opini audit going concern. Berdasarkan penjelasan tersebut maka hipotesis selanjutnya adalah:

H6: Debt to equity ratio berpengaruh positif terhadap kemungkinan penerimaan opini audit going concern.

Kerangka Berfikir. Secara skematis, berdasarkan landasan teori dan penelitian terdahulu yang telah dikemukakan di atas, maka hipotesis yang dimunculkan desain penelitian untuk menggambarkan alur permasalahan dan jawaban yang diharapkan serta model pengujiannya dapat digambarkan sebagai berikut:

\begin{tabular}{|c|c|}
\hline Kualitas audit & H1 \\
\hline $\begin{array}{l}\text { Kontisi keuang } \\
\text { perusahaan }\end{array}$ & $\mathrm{H} 2$ \\
\hline $\begin{array}{l}\text { opini audit taiur } \\
\text { sebelumnya }\end{array}$ & $\mathrm{H} 3$ \\
\hline $\begin{array}{l}\text { Pertimbuhan } \\
\text { Pperusahaan }\end{array}$ & H4 \\
\hline $\begin{array}{l}\text { Ukwan } \\
\text { penusahaan }\end{array}$ & H5 \\
\hline $\begin{array}{l}\text { Utang (DBbt ic } \\
\text { Equity Ratio) }\end{array}$ & H5 \\
\hline
\end{tabular}

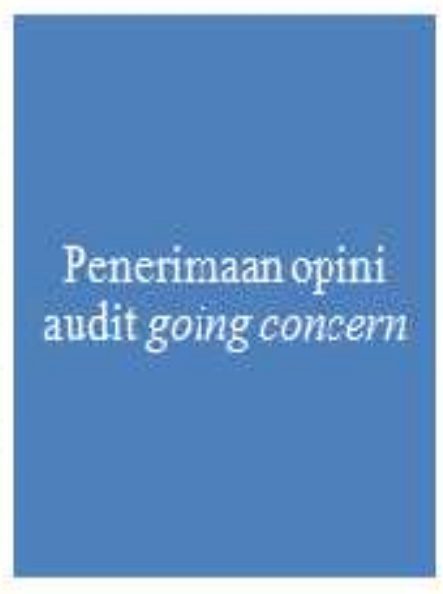

\section{METODE}

Pengumpulan data dan pemilihan sampel. Penelitian ini merupakan penelitian kuantitatif dengan populasi yang digunakan adalah seluruh perusahaan manufaktur yang terdaftar di Bursa Efek Indonesia tahun 2008-2012.Metode Penelitian yang digunakan dalam penelitian ini adalahpurposive sampling yaitu teknik pengambilan sampel dengan pertimbangan atau kriteria tertentu (Sugiyono, 2007). Kriteria yang dipertimbangkan dalam pengambilan sampel penelitian ini adalah sebagai berikut: (1) Auditee sudah terdaftar di Bursa Efek Indonesia (BEI) sebelum 1 Januari 2008. (2) Menerbitkan laporan keuangan yang telah diaudit oleh auditor independen selama tahun 2008-2012. (2) Mengalami laba bersih setelah pajak yang negatif sekurangnya 2 periode laporan 
keuangan ( 2 tahun) secara berturut-turut. Hal ini dikarenakan auditor hampir tidak pernah mengeluarkan opini going concern pada perusahaan yang mempunyai laba bersih setelah pajak positif (McKeown et.al,. 1991).

Identifikasi dan Pengukuran Variabel. Opini audit going concern. Opini audit going concern merupakan opini audit modifikasi yang dalam pertimbangan auditor terdapat ketidakmampuan atau ketidakpastian signifikan atas kelangsungan hidup perusahaan dalam menjalankan operasinya di masa mendatang. Termasuk dalam opini going concern ini adalah, opini wajar tanpa pengecualian dengan bahasa penjelas, opini wajar dengan pengecualian, opini tidak wajar, dan tidak memberikan pendapat (Ramadhany, 2004).

Setyarno et.al., (2006) menyebutkan going concern adalah kelangsungan hidup suatu entitas. Dengan adanya going concern maka suatu entitas dianggap akan mampu mempertahankan kegiatan usahanya dalam jangka panjang, tidak akan dilikuidasi dalam jangka waktu pendek.Opini audit going concern ini diukur dengan menggunakan variabel dummy dimana kategori 1 untuk auditee yang menerima opini audit going concern dan kategori 0 untuk auditee yang menerima opini audit non going concern.

Kualitas Audit. Kualitas audit atau yang juga sering disebut dengan reputasi auditor adalah tempat KAP yang mengaudit laporan keuangan tersebut apakah berasal dari the big four atau tidak. KAP yang dimaksud dengan the big four adalah, (1) KPMG yang berafiliasi dengan Siddharta \& Widjaja, (2) Ernst dan Young berafiliasi dengan Purwantono, Sarwoko \& Sandjaja, (3) Osman Bing Satrio dan Rekan berafiliasi dengan Deolitte Touche Tohmatsu, dan (4) Haryantono Sahari dan Rekan bearfiliasi dengan PricewaterhouseCoopers. Kualitas audit diukur dengan menggunakan variabel dummy, yaitu diberikan kode 1 jika KAP berafiliasi dengan KAP the big four, dan diberikan kode 0 jika KAP tidak berafiliasi dengan KAP the big four (Setyarno et.al., 2006).

Kondisi Keuangan Perusahaan. Kondisi keuangan perusahaan adalah tingkat kesehatan perusahaan sesungguhnya (Ramadhany, 2004).Dalam penelitian ini kondisi keuangan perusahaan diproksikan dengan menggunakan model prediksi kebangkrutan Altman ZScore. Rumus yang digunakan adalah:

$Z 1=$ working capital $/$ total asset

$Z 2=$ retained earnings $/$ total asset

$Z 3=$ earnings before interest and taxes / total asset

$Z 4=$ book value of equity / book value of debt

$Z 5=$ sales $/$ total asset

Nilai $Z$ diperoleh dengan menghitung kelima rasio tersebut berdasarkan data pada neraca dan laporan laba/rugi, dikalikan dengan koefisien masing-masing rasio kemudian dijumlahkan hasilnya. Hasil perhitungan $Z$ Score ini berupa skala rasio.

Pertumbuhan Perusahaan. Pertumbuhan perusahaan dalam penelitian ini diproksikan dengan rasio pertumbuhan penjualan (Setyarno et.al., 2006). Rasio pertumbuhan penjualan digunakan untuk mengukur kemampuan perusahaan dalam pertumbuhan tingkat penjualannya dibandingkan dengan tahun sebelumnya. Data ini diperoleh dengan menghitung sales growth ratio berdasarkan laporan laba/rugi masing-masing auditee. Hasil perhitungan rasio pertumbuhan penjualan disajikan dengan skala rasio. 


$$
\text { Pertumbuhan Penjualan }=\frac{\text { Penjualan Bersih }}{t-\text { Penjualan Bersih }_{t-1}}
$$

Opini Auditor Sebelumnya. Opini auditor sebelumnya didefinisikan sebagai opini audit yang diterima oleh auditee pada tahun sebelumnya yang diukur dengan menggunakan variabel dummy yaitu, diberikan kode 1 apabila auditee menerima opini audit going concern, sedangkan apabila auditee menerima opini audit non going concern diberikan kode 0 (Ramadhany, 2004).

Ukuran Perusahaan. Ukuran perusahaan merupakan suatu skala yang dapat mengklasifikasikan perusahaan menjadi perusahaan besar, menengah, dan kecil. Ukuran perusahaan dalam penelitian ini diukur melalui logaritma total aset. Total aset dipilih sebagai proksi atas ukuran perusahaan dengan mempertimbangkan, bahwa nilai aset relatif lebih stabil dibandingkan dengan nilai market capitalized dan penjualan (Rahman dan Siregar, 2012)

Debt to Equity Ratio. Rasio ini menunjukkan proporsi atas penggunaan utang untuk membiayai investasi perusahaan. Debt to equity ratio dalam penelitian ini diukur dengan membandingkan antara total kewajiban dengan total equity. Rasio ini mengukur sejauhmana aset perusahaan dibelanjai dengan kewajiban yang berasal dari kreditor dan modal sendiri yang berasal dari pemegang saham.Debt to Equity Ratio = Total Utang / Total Ekuitas

Analisis Data. Penelitian ini menggunakan pendekatan kuantitatif. Ditinjau dari segi tujuannya penelitian ini merupakan penelitian deduktif yaitu tipe penelitian yang bertujuan untuk menguji hipotesis melalui validasi teori atau pengujian aplikasi teori pada keadaan tertentu. Pengolahan data dilakukan dengan analisis statistik inferensial untuk pengujian hipotesis yang diajukan. Pengujian hipotesis dilakukan dengan analisis multivariat dengan menggunakan regresi logistik (logistic regression). Berikut langkah pengujian hipotesis dengan menggunakan regresi logistik(logistic regression) yaitu; (1) Menilai Keseluruhan Model (Overall Model Fit). (2)Menganalisis Koefisien Determinasi (Nagelkerke $R$ Square). (3)Menilai Kelayakan Model Regresi. (4) Menyusun Model Regresi Logistik.Berikut model regresi logistik dalam penelitian ini:

$$
G C O=\alpha+\beta 1 \mathrm{ADQ}+\beta 2 \mathrm{ZSC}+\beta 3 \mathrm{PRO}+\beta 4 \mathrm{SLR}+\beta 5 \mathrm{SIZ}+\beta 6 \mathrm{DER}+\varepsilon
$$

Keterangan: $G C O=$ Opini going concern (variabel dummy, 1 untuk auditee dengan opini audit going cocern (GCAO) dan 0 untuk auditee dengan opini audit non going concern (NGCAO); $\alpha=$ Konstanta; $\beta i=$ Koefisien regresi; ADQ $=$ Kualitas auditor yang diproksikan variabel dummy (1 untuk sauditor yang tergabung skala besar (big 4) dan 0 untuk yang bukan (non big 4); ZSC = Kondisi keuangan perusahaan yang diproksikan dengan menggunakan lima model prediksi kebangkrutan Altman Zscore untuk perusahaan manufaktur; $\mathrm{PRO}=$ Opini audit yang diterima pada tahun sebelumnya (kategori 1 bila opini audit going concern (GCAO), 0 bila bukan (NGCAO); SLR = Rasio pertumbuhan penjualan auditee; SIZ = Ukuran perusahaan; DER = Debt to equity ratio; $\varepsilon=$ Kesalahan residual. 


\section{HASIL DAN PEMBAHASAN}

Deskripsi Sampel Penelitian. Populasi dalam penelitian ini adalah perusahaan manufaktur yang terdaftar di Bursa Efek Indonesia pada periode 2008-2012. Sampel yang di gunakan dalam penelitian ini berdasarkan metode purposive sampling dengan menggunakan kriteria-kriteria yang telah di tentukan. Total sampel penelitian adalah sebanyak 98 sampel (20 auditee). Proses penentuan sampel di tunjukkan sebagaimana terlihat dalam Tabel 1.

Tabel 1. Proses Penentuan Sampel

\begin{tabular}{clcc}
\hline No & \multicolumn{1}{c}{ Kriteria } & $\begin{array}{c}\text { Pelanggaran } \\
\text { Kriteria }\end{array}$ & Jumlah \\
\hline 1 & $\begin{array}{l}\text { Auditee sudah terdaftar di Bursa Efek Indonesia (BEI) } \\
\text { sebelum 1 Januari 2008. }\end{array}$ & - & 145 \\
2 & $\begin{array}{l}\text { Menerbitkan laporan keuangan yang telah diaudit oleh } \\
\text { auditor independen selama tahun 2008 - 2012. }\end{array}$ & 11 & \\
$3 \quad \begin{array}{l}\text { Mengalami laba bersih setelah pajak yang negatif } \\
\text { sekurangnya 2 periode laporan keuangan (2 tahun) secara } \\
\text { berturut-turut. }\end{array}$ & 110 & 24 \\
$\quad \begin{array}{l}\text { Memiliki data laporan keuangan yang di audit oleh auditor } \\
\text { independen. }\end{array}$ & 4 & 20 \\
Jumlah sampel selama 5 tahun (20x5) & 100 & \\
Tahun 2009, 1 perusahaan tidak melampirkan 2 data laporan \\
keuangannya. \\
Total sampel selama periode penelitian 2008-2012
\end{tabular}

Sumber: Hasil pengolahan data, 2014.

Variabel dependen dalam penelitian ini adalah opini audit going concern. Klasifikasi perolehan opini tersebut sebagaimana terlihat pada tabel IV 2.

Tabel 2. Klasifikasi Penerimaan Opini Audit Going Concern

\begin{tabular}{c|cccccc|c}
\hline \multirow{2}{*}{ Opini Audit } & \multicolumn{5}{|c|}{ Tahun } & \multirow{2}{*}{ Jumlah } \\
\cline { 2 - 6 } & 2008 & 2009 & 2010 & 2011 & 2012 & \\
\hline Going Concern & 14 & 11 & 5 & 9 & 5 & 44 \\
Non Going Concern & 6 & 8 & 14 & 11 & 15 & 54 \\
$\quad$ Jumlah & 20 & 19 & 19 & 20 & 20 & 98 \\
\hline
\end{tabular}

Sumber: ICMD berdasarka hasil seleksi 2014

Jumlah auditee yang menerima opini audit going concern selama periode penelitian20082012 sebanyak 44 perusahaan dengan total sampel 98auditee. Pada tahun 2008 total perusahaan yang menerima opini audit going concern sebanyak 14auditee, sedangkan tahun 2009 sebanyak 11 perusahaan. Tahun 2010 sebanyak 5 perusahaan, tahun 2011 sebanyak 9 perusahaan dan tahun 2012, sebanyak 5 auditee menerima opini audit going concern.

Analisis Data. Menilai Keseluruhan Model (Overall Model Fit). Analisis pertama yang di lakukan adalah menilai overall model fit terhadap data penelitian sebagaimana terlihat pada Tabel 3. 
Tabel 3. Perbandingan Nilai $-2 \log L$

\begin{tabular}{cc}
\hline Keterangan & Nilai \\
\hline$-2 \log$ L $($ Block Number $=0)$ & 134.835 \\
$-2 \log$ L $($ Block Number $=1)$ & 120.165 \\
\hline
\end{tabular}

Sebagaimana terlihat dalam tabel 3 bahwa perbandingan nilai antara -2 Log Likelihood (2 Log L) pada awal (Block Number $=0$ ) dengan nilai -2 Log L Akhir (Block Number = 1)mengalami penurunan, sehingga dapat di katakan bahwa model yang di hipotesiskan fit dengan data.

Menganalisis Koefisien Determinasi (Nagelkerke $\boldsymbol{R}$ Square). Besarnya nilai koefisien determinasi pada model regresi logistik di tunjukkan oleh nilai Nagelkerke $R$ Square sebagaimana terlihat dalam tabel 4 . Berdasarkan data dari tabel tersebut dapat di lihat bahwa nilai Nagelkerke $R$ Square adalah sebesar $+0,186$, sehingga variabilitas variabel dependen yang dapat di jelaskan oleh variabel independen adalah sebesar 18,6\%, sedangkan sisanya sebesar $81,4 \%$ di jelaskan oleh variabel-variabel lain di luar model penelitian. Hal tersebut menunjukkan bahwa secara bersama-sama variasi variabel bebas (kualitas audit, kondisi keuangan perusahaan, pertumbuhan perusahaan, opini audit tahun sebelumnya, ukuran perusahaan, dan debt to equity ratio) dapat menjelaskan variasi variabel going concern sebesar 18,6\%.

Tabel 4. Nilai Nagelkerke R Square

\begin{tabular}{lccc}
\hline Step & -2 Log likelihood & Cox \& Snell R Square Nagelkerke R Square \\
\hline 1 & $120.165^{\text {a }}$ & 0.139 & 0.186 \\
\hline $\begin{array}{l}\text { a. Estimation terminated at iteration number } 8 \text { because parameter estimates } \\
\text { changed by less than .001. }\end{array}$ \\
\hline
\end{tabular}

Menilai Kelayakan Model Regresi. Pengujian hipotesis selanjutnya adalah menilai kelayakan model regresi logistik yang akan di gunakan. Hasil pengujian dapat di lihat dalam Tabel 5.

Tabel 5. Kelayakan Model Regresi

\begin{tabular}{cccc}
\hline \multicolumn{3}{c}{ Hosmer and Lemeshow Test } \\
\hline Step & Chi-square & Df & Sig. \\
1 & 10.008 & 8 & 0.264 \\
\hline
\end{tabular}

Tabel diatas menunjukkan bahwa pengujian Hosmer and Lemeshow adalah sebesar $+0,264$. Dari hasil tersebut, maka dapat di katakan bahwa H0di terima, yang mana hal tersebut dikarenakan nilai signifikansi yang di peroleh lebih besar daripada $+0,05$. Oleh karena nilai signifikansi yang di peroleh jauh di atas +0.05 , sehingga dapat di simpulkan bahwa model mampu memprediksi nilai observasinya atau dapat di katakan pula model dapat diterima karena sesuai dengan data observasinya. 
Matriks Klasifikasi Model. Matriks klasifikasi menunjukkan kekuatan prediksi dari model regresi untuk memprediksi kemungkina penerimaan opini audit going concern pada perusahaan manufaktur di BEI. Sebagaimana di tunjukkan pada tabel 6 nilai matriks klasifikasi dapat dilihat dari Classification Table.

Tabel 6. Classification Table

\begin{tabular}{|c|c|c|c|c|c|}
\hline \multirow{3}{*}{\multicolumn{2}{|c|}{ Observed }} & & \multicolumn{3}{|c|}{ Predicted } \\
\hline & & & \multicolumn{2}{|c|}{ OGC } & \multirow{2}{*}{ Percentage Correct } \\
\hline & & & .00 & 1.00 & \\
\hline \multirow[t]{3}{*}{ Step 1} & OGC & .00 & 40 & 14 & 74.1 \\
\hline & & 1.00 & 19 & 25 & 56.8 \\
\hline & Overa & Percentage & & & 66.3 \\
\hline \multicolumn{3}{|c|}{ a. The cut value is .500} & & & \\
\hline
\end{tabular}

Dalam Tabel 6 dapat diketahui bahwa kekuatan prediksi dari model regresi untuk memprediksi kemungkinan perusahaan menerina opini audit going concern adalah sebesar $56,8 \%$. Hal ini menunjukkan bahwa dengan menggunakan model regresi yang digunakan, terdapat sebanyak 25 laporan keuangan yang diberi opini audit going concern dari total 44 laporan keuangan yang seharusnya diberi opini audit going concern. Kekuatan prediksi model perusahaan yang tidak menerima opini audit going concern adalah sebesar $74,1 \%$, yang berarti bahwa dengan model regresi yang digunakan ada sebanyak 40 laporan keuangan yang diberi opini non going concern dari total 54 laporan keuangan yang seharusnya diberi opini audit non going concern.Tabel tersebut menunjukkan bahwa tingkat prediksi model adalah sebesar $66,3 \%$, dimana $56,8 \%$ going concern dan $74,1 \%$ non going concern telah mampu di prediksi oleh model. Artinya kemampuan prediksi dari model dengan variabelkaulitas audit, kondisi keuangan perusahaan, pertumbuhan perusahaan, opini audit tahun sebelumnya, ukuran perusahaan, dan debt to equity ratio secara statistik dapat memprediksi sebesar $66,3 \%$.

Estimasi Parameter dan Interpretasinya. Estimasi parameter dapat dilihat melalui koefisien regresi (Variables in The Equation) dimana pengujian koefisien regresi tersebut menggunakan regresi logistik sebagaimana terlihat dalam Tabel 7.

Adapun model yang di hasilkan dari pengujian terhadap model regresi adalah sebagai berikut:

$$
\begin{aligned}
G C O= & -3,930+-1,245 \mathrm{ADQ}+0,025 \mathrm{ZSC}+0,316 \mathrm{PRO}+0,214 \mathrm{SLR}+0,664 \mathrm{SIZ}+ \\
& 0,007 \mathrm{DER}+\varepsilon
\end{aligned}
$$

Pengujian hipotesis dengan regresi logistik terlihat pada kolom signifikan (sig)di tabel 7, kemudian dibandingkan dengan nilai signifikansi $(\alpha)$ yang digunakan, yaitu $+0,05$ (5\%). Apabila tingkat signifikan $<+0,05$, maka $\mathrm{H} 1$ diterima, jika tingkat signifikan $>+0,05$ maka H1 ditolak. Sedangkan nilai (B) atau koefisien regresi pada tabel tersebut menunjukkan hubungan Antara variable independen dan variable dependen. 
Tabel 7. Variables in The Equation

\begin{tabular}{llcccccc}
\hline & & B & S.E. & Wald & df & Sig. & $\operatorname{Exp(B)}$ \\
\hline Step 1 $^{\text {a }}$ & KA & -1.245 & 0.535 & 5.427 & 1 & 0.020 & 0.288 \\
& KKP & 0.025 & 0.360 & 0.005 & 1 & 0.944 & 1.026 \\
& PP & 0.316 & 0.310 & 1.039 & 1 & 0.308 & 1.372 \\
& OATS & 0.214 & 0.450 & 0.225 & 1 & 0.635 & 1.238 \\
& UP & 0.664 & 0.366 & 3.284 & 1 & 0.070 & 1.942 \\
& DER & 0.007 & 0.006 & 1.319 & 1 & 0.251 & 1.007 \\
& Constant & -3.930 & 2.117 & 3.445 & 1 & 0.063 & 0.020 \\
\hline
\end{tabular}

a. Variable(s) entered on step 1: KA, KKP, PP, OATS, UP, DER.

Pengaruh kualitas audit terhadap penerimaan opini audit going concern. Sebagaimana ditunjukkan pada tabel 7 bahwa koefisien dari kualitas audit adalah -1,245 dengan tingkat signifikansi +0,02. Maka hipotesis pertama $(\mathrm{H} 1)$ dalam penelitian ini ditolak karena signifikansi variabel tersebut $<+0,05$ dan memiliki nilai koefisiennegatif. Variabel kualitas audit berpengaruh signifikan tetapi nilai koefisiennya negatif, maka dapat dikatakan variabel tersebut memiliki hubungan berlawanan. Dengan demikian dapat dikatakan pula bahwa semakin besar ukuran KAP, maka semakin kecil peluang perusahaan menerima opini audit going concern. Hasil ini berlawanan karena perusahaan yang menjadi sampel sendiri adalah perusahaan yang mengalami rugi, sehingga auditor besar kemungkinan kecil akan memberikan opini going concern pada perusahaan rugi. Signifikansi yang menunjukkan $<0,05$, maka reputasi auditor dapat dikatakan berpengaruh signifikan negatif terhadap penerimaan opini audit going concern. Hasil penelitian ini konsisten dengan penelitian Januarti (2009) dimana variabel kualitas audit (big four) berpengaruh negatif signifikan atas kemungkinan penerimaan opini audit going concern.

Kantor Akuntan Publik baik berskala besar maupun yang berskala kecil akan bersikap obyektif dalam memberikan pendapat. Hal ini membuktikan bahwa KAP yang berafiliasi dengan pihak internasional yang memiliki kredibilitas yang cukup, belum tentu mengeluarkan opini audit going concern pada perusahaan, sehingga anggapan bahwa hanya KAP yang besar saja yang mengeluarkan opini audit terpercaya dan berkualitas dapat ditepis. Kemungkinan KAP yang tidak berskala besar juga memiliki kredibilitas dalam mengeluarkan opini audit going concern. Oleh karena itu jika suatu perusahaan mengalami keraguan dalam kelangsungan hidupnya, maka KAP besar kemungkinan akan memberikan opini audit non going concern sesuai dengan kondisi perusahaan tersebut.

Pengaruh kondisi keuangan perusahaanterhadap penerimaan opini auditgoing concern. Sebagaimana ditunjukkan pada tabel 7 bahwa koefisien dari kondisi keuangan perusahaan adalah $+0,025$ dengan tingkat signifikansi $+0,944$. Artinya hipotesis kedua (H2) dalam penelitian ini ditolak, karena signifikansi variabel tersebut $>+0,05$. Dengan demikian dapat dikatakan variabel kondisi keuangan perusahaan berpengaruh tidak signifikan terhadap penerimaan opini audit going concern.

Penelitian ini gagal membuktikan adanya pengaruh signifikan kondisi keuangan perusahaan terhadap penerimaan opini audit going concern.Walaupun variabel kondisi keuangan perusahaan tidak berpengaruh signifikan tetapi tanda dari nilai koefisien adalah 
positif, maka dapat dikatakan variabel tersebut memiliki hubungan searah. Dengan demikian dapat dikatakan pula bahwa semakin tinggi ketidakmampuan perusahaan memenuhi kewajiban, semakin besar pula kemungkinan perusahaan tidak menerima opini audit going concern.

Hasil penelitian ini selaras dengan penelitian Rahman dan Siregar (2012) dan Arga dan Wedari (2007), bahwa perusahaan yang mengalami masalah keuangan tidak berpengaruh terhadap opini audit going concern. Auditor akan sangat memperhatikan kondisi keuangan perusahaan dalam menerbitkan opini audit going concern, sehingga apabila perusahaan mengalami kesulitan dalam masalah keuangan maka belum tentu auditor akan memberikan pendapatnya terhadap kelangsungan hidup perusahaan tersebut.

Pengaruh pertumbuhan perusahaan terhadap kemungkinan penerimaan opini audit going concern. Sebagaimana ditunjukkan pada tabel 7 bahwa koefisien dari pertumbuhan perusahaan adalah $+0,316$ dengan tingkat signifikansi $+0,308$. Artinya (H3) dalam penelitian ini ditolak, karena signifikansi variabel tersebut $>+0,05$. Hasil ini selaras dengan penelitian Fany dan Saputra (2005) serta Setyarno et.al., (2006) bahwa rasio pertumbuhan perusahaan yang positif belum tentu menjamin auditee untuk tidak mendapatkan opini audit going concern. Dari sampel perusahaan yang diteliti mengalami pertumbuhan rasio penjualan yang negatif, hal itu bisa jadi dikarenakan meningkatnya biaya-biaya operasional dibandingkan laba. Sehingga pertumbuhan perusahaan tidak berpengaruh terhadap penerimaan opini audit going concern.

Pengaruh opini audit tahun sebelumnya terhadap kemungkinan penerimaan opini audit going concern. Sebagaimana ditunjukkan pada tabel 7 bahwa koefisien dari pertumbuhan perusahaan adalah $+0,214$ dengan tingkat signifikansi $+0,635$. Artinya $(\mathrm{H} 4)$ ditolak, karena signifikansi variabel tersebut $>+0,05$. Meskipun hasil statistik dari penelitian ini tidak berpengaruh tetapi opini audit tahun sebelumnya tetap akan menjadi acuan bagi auditor untuk memberikan pendapat pada periode berjalan.Hasil penelitian ini selaras dengan penelitian dari Santosa dan Wedari (2007), bahwasanya belum tentu auditor memberikan pendapatnya yang sama dengan tahun sebelumnya namun tetap melihat kondisi keseluruhan perusahaan pada saat itu, dengan mengamati kondisi keuangan dan kondisi lain yang mendukung untuk memberikan pendapat pada auditee.

Pengaruh ukuran perusahaan terhadap kemungkinan penerimaan opini audit going concern. Sebagaimana ditunjukkan pada tabel 7 bahwa koefisien dari pertumbuhan perusahaan adalah $+0,664$ dengan tingkat signifikansi $+0,070$. Artinya (H5) dalam penelitian ini ditolak, karena signifikansi variabel tersebut $>+0,05$. Dengan demikian dapat dikatakan variabel ukuran perusahaan berpengaruh tidak signifikan terhadap penerimaan opini audit going concern.Penelitian ini gagal membuktikan adanya pengaruh signifikan ukuran perusahaan terhadap penerimaan opini audit going concern. Hasil penelitian ini konsisten dengan Ramadhany (2004) bahwa ukuran perusahaan tidak berpengaruh signifikan. Penelitian ini juga mendukung hasil temuan dari penelitian Junaidi dan Hartono (2010).

Tanda dari nilai koefisien regresivariabel ukuran perusahaan adalah positif, yang artinya semakin rendah aset atau ukuran perusahaan, kecil kemungkinan akan mendapatkan opini audit going concern. Hal ini disebabkan pertumbuhan aktiva tidak diikuti dengan kemampuan auditee untuk meningkatkan saldonya. Artinya KAP dalam 
melaksanakan proses auditing pada perusahaan tidak terpengaruh pada ukuran perusahaan besar atau kecil.

Pengaruh Debt to equity ratio terhadap kemungkinanpenerimaan opini audit going concern. Sebagaimana ditunjukkan pada tabel 7 bahwa koefisien dari pertumbuhan perusahaan adalah $+0,007$ dengan tingkat signifikansi $+0,251$. Artinya hipotesis kelima (H6) dalam penelitian ini ditolak, karena signifikansi variabel tersebut $>+0,05$. Dengan demikian dapat dikatakan variabel debt to equity ratio berpengaruh tidak signifikan terhadap penerimaan opini audit going concern.

Hal ini berarti opini audit going concern tidak di berikan kepada perusahaan yang memiliki rasio DER tinggi maupun rendah. Kondisi ini mungkin disebabkan karena auditor dalam memberikan pendapat tidak melihat dari kemampuan saldo perusahaan yang didapatkan dari kreditor maupun modal intern dari pemegang saham. Namun hasil statistik penelitian ini bernilai positif, artinya perusahaan akan memilih modal eksternal (utang) yang lebih besar daripada modal internal karena mudah untuk didapatkan. Penelitian ini selaras dengan penelitian Susanto (2009) bahwasanya auditor dalam memberikan opini tidak melihat dari sejauhmana modal perusahaan dalam menutup hutang dari pihak luar tetapi dari kondisi keuangan perusahaan secara keseluruhan.

Tabel 8. Ringkasan Pengujian Hipotesis

\begin{tabular}{cccc}
\hline Hipotesis & Hasil & Signifikasi (Sig) & Nilai Koefisien Regresi (B) \\
\hline H1 & Ditolak & 0,020 & $-1,245$ \\
H2 & Ditolak & 0,944 & 0,025 \\
H3 & Ditolak & 0,308 & 0,316 \\
H4 & Ditolak & 0,635 & 0,214 \\
H5 & Ditolak & 0,070 & 0,664 \\
H6 & Ditolak & 0,251 & 0,007 \\
\hline
\end{tabular}

\section{PENUTUP}

Penelitian ini dilakukan untuk mengetahui pengaruh yang diberikan oleh kualitas audit, kondisi keuangan perusahaan, pertumbuhan perusahaan, opini audit tahun sebelumnya, ukuran perusahaan, dan debt to equity ratio terhadap penerimaan opini audit going concern pada perusahaan manufaktur di BEI selama tahun 2008-2012. Dari hasil penelitiandapat ditarik kesimpulan bahwa kualitas auditberpengaruh negatif signifikan terhadap penerimaan opini audit going concern (H1), kondisi keuangan perusahaan $(\mathrm{H} 2)$, pertumbuhan perusahaan (H3), opini audit tahun sebelumnya $(\mathrm{H} 4)$, ukuran perusahaan (H5), dan debt to equity ratio (H6) berpengaruh tidak signifikan terhadap penerimaan opini audit going concern. Mengingat penelitian ini hanya berfokus pada perusahaan manufaktur yang terdaftar di Bursa Efek Indonesia, serta penelitian yang hanya dilakukan selama lima tahun, kedepannya diharapkan penelitian ini dapat dikembangkan denganmenambah/memperluas sampel penelitiannya (jasa, perbankan, transportasi, dan sebagainya), sehingga penelitian tersebut lebih representatif dan hasilnya lebih dapat digeneralisir. Diharapakan pula peneliatian selanjutnya dapat menambah rentang waktu penelitian, sehingga kecenderungan dari trend penerbitan opini audit going concern oleh auditor dalam jangka panjang dapat diprediksi. Selain itu diharapkan juga dapat 
menambah variabel-variabel lain yang lebih menyentuh aspek audit perusahaan, sehingga model penelitian dapat semakin baik dan hasilnya dapat digeneralisir.

\section{DAFTAR RUJUKAN}

Altman, E.I. (1968) "Financial Ratios, Discriminant Analysis and the Prediction of Corporate Bankruptcy". Journal of Finance 23:189-209.

Altman, E.I. and T.P. MGouh. (1974) "Evolution of a Company as a Going Concern". The Journal of Accoutancy, 50-57.

Arens, Alvin. A dan Loebbecke. (1997) Auditing Pendekatan Terpadu. Jakarta: Salemba Empat.

Arga, Fajar Santosa, dan Wedari, Linda Kusumaning. (2007) "Analisis faktor-faktor yang mempengaruhi kecenderungan audit going concern". Jurnal Ilmiah Akuntansi Volume 11 (2), Desember 2007: 141-158, Semarang.

Careello, J. V., \& Neal, T. L. (2000) "Audit Committee Composition and Auditor Reporting". The Accounting Review, 75(4), 453-467.

Chen, K. C. W., and B. K. Church. (1992) "Default on Debt Obligation and the Issuance of GoingConcern Report".Auditing: A Journal of Practice \& Theory, Fall. 30 - 49

Craswell, C., Willetts, L., Murrary, L., Singhal, M., \& Cooper, P. (2008) Treatment of child anxiety: An exporatory study of the role of maternal anxiety and behaviours in treatment. Behavior Research and Therapy, 43, 1375-1381.

DeAngelo, L. (1981) “Auditor Size and Audity”. Journal Of Accounting and Economics, 3, 183-199.

Eisenhardt, K. M. (1989) Building theories from case study research. Academy of Management Review, 14: 532-550.

Fanny, Margaretta dan Saputra, S. (2005) Opini Audit Going Concern: Kajian Berdasarkan Model Prediksi Kebangkrutan, Pertumbuhan Perusahaan, Dan Reputasi Kantor Akuntan Publik (Studi Pada Emiten Bursa Efek Jakarta). Simposium Nasional Akuntansi VIII. 966-978. Denpasar Bali pada tanggal 2 dan 3 Desember 2004.

Hartono, (2010). SPSS 16.0 Analisis Data Statistik dan Penelitian Edisi-2. Yogjakarta: PUSTAKA PELAJAR

Januarti, Indira dan Fitrianasari, Ella. (2008) "Analisis Rasio Keuangan dan Rasio Non Keuangan yang Mempengaruhi Auditor dalam Memberikan Opini Audit Going Concern pada Auditee (Studi Empiris pada Perusahaan Manufaktur yang terdaftar di BEJ tahun 2000-2005)". Jurnal Maksi, UNDIP Vol. 8, (1), pp. 43-58.

Januarti, Indira. (2009) Analisis Pengaruh Faktor Perusahaan, Kualitas Auditor, Kepemilikan Perusahaan terhadap Penerimaan Opini Audit Going Concern (Perusahaan Manufaktur yang terdaftar di Bursa Efek Indonesia). Simposium Nasional Akuntansi XII (6): 1-26.

Jensen, C. Michael and Meckling H. William. (1976) Theory of the Firm: Managerial Behavior, Agency Costs and Ownership Structure. Journal of Financial Economics.

Junaidi, dan Hartono, Jogiyanto. (2010) FaktorNonkeuangan pada Opini Going concern. Makalah Disampaikan dalam Simposium Nasional Akuntansi XIII. Purwokerto: 1315 Oktober. 
Koh, HC, Killough LN. (1990) The Use Of Multiple Discriminant Analysis in The Assessment of the Going concern Status of an Audit Client. J Bus Finance Accountant 17(2): 179-192.

Koh HC. (1991) Model Predictions and Auditor Assessments of Going concern Status. Account Buss Res 21(84): 331-338.

Krishnan, KR, Gade KM. (1996) The Pathophysiologycal Basis of Late-life Depression: Immaging Studies of The Aging Brain. Am J Geriatr Psychiatry. 4:22-33

McKeown, M. G., Beck, I. L., Sinarta, G. M., \& Loxterman, J. A. (1991) The Contribution of Prior Knowladge and Coherent Text Comprehension. (Submitter for Publication).

Mulyadi. (2002) Auditing. Buku I. Yogyakarta: Salemba Empat.

Munawir, H.S. (1997) Auditing Modern. Buku I. Yogyakarta. BPFE.

Mutchler, C.K, and J.D. Greer. (1984) Reduced Tillage for Soybeans, Trans. ASAE 27:1364-1369.

Mutchler, C.K., L.L. McDowell, and J.D. Gree. (1985) Soil Loss From Cotton With Conservation Tillage, Trans. ASSAE 28:160-163, 168.

Mutchler, J. F., Hopwood, W., \& McKeon, J. C. (1997) "The Influence of Contrary Information and Mitigating Factors on Audit Opinion Decisions on Bankrupt Companies". Journal of Accounting Research, 35(w), 295-310.

Praptitorini, Mirna Dyah dan Januarti, Indira. (2007) Analisis Pengaruh Kualitas Audit, Debt Default, dan Opinion Shopping terhadap Penerimaan Opini Going Concern. Makalah Disampaikan dalam Simposium Nasional Akuntansi X. Makassar: 26-28 Juli.

Rahman, Abdul dan Siregar, Baldric. (2012) Faktor-faktor yang mempengaruhi kecenderungan penerimaan opini audit going concern pada perusahaan manufaktur yang terdaftar di bursa efek Indonesia. Makalah Disampaikan dalam Simposium Nasional Akuntansi XV. Banjarmasin: 22-23 September.

Ramadhany, Alexander. (2004) Analisis Faktor-faktor yang Mempengaruhi Penerimaan Opini Going concern Pada Perusahaan Manufaktur yang Mengalami Financial Distress di Bursa Efek Jakarta . Tesis Program Studi Magister Akuntansi Program Pascasarjana Universitas Diponegoro. Semarang.

Ruiz-Barbadillo, E., Gomez-Aguilar, N., De Fuentes-Barbera, C. and Garcia-Benua, M.A. (2004) Audit Quality and the Going concern Decision-Making Process: Spanish Evidence. Europen Accounting Review, 13(4): 597-620.

Santosa, Arga Fajar dan Linda Kusumaning Wedari. (2007) "Analisis Faktor-faktor yang Mempengaruhi Penerimaan Opini Audit Going Concern”. JAAI Volume 11 (2) Desember 2007: 141

Saputra,Puji. (2012) Analisis Faktor-faktor yang Mempengaruhi Penerimaan Opini Audit Going concern Pada Perusahaan Manufaktur di Bursa Efek Indonesia. Skripsi Program Studi Akuntansi Universitas Muhammadiyah Surakarta. Surakarta.

Sekaran, Uma. (2009) Metodologi Penelitian untuk Bisnis. Jakarta: Salemba Empat.

Setyarno, Eko Budi, Indira Januarti dan Faisal. (2006) Pengaruh Kualitas Audit, Kondisi Keuangan Perusahaan, Opini Audit Tahun Sebelumnya, Pertumbuhan Perusahaan Terhadap Opini Audit Going Concern. Makalah Disampaikan dalam Simposium Nasional Akuntansi IX. Padang: 23-26 Agustus.

Sugiyono. (2007) Metode Penelitian Kuantitatif Kualitatif dan R\&D. Bandung: Alfabeta Sujianto. (2001) Dasar-dasar management Keuangan. Yogyakarta: BPFE 
Susanto, Yulius Kurnia. (2009) "Faktor-faktor yang Mempengaruhi Penerimaaqn Opini Audit Going concern pada Perusahaan Publik Sektor Manufaktur". Jurnal Bisnis dan Akuntansi Volume 11 (3) Desember 2009: 155-173

Weston, J. Fred dan Thomas E. Copeland, (1992). Managerial Finance. The Dryden Press, Edisi ke 9.

Windyantari, Ayu Putri. (2011) Opini Audit Going -158.Concern dan Faktor-Faktor yang Memengaruhi: Studi pada Perusahaan Manufaktur di Bursa Efek Indonesia. Tesis Program Studi Magister Akuntansi Program Pascasarjana Universitas Udayana. Denpasar. 